\title{
Oxidative stress augments toll-like receptor 8 mediated neutrophilic responses in healthy subjects
} Satoru Yanagisawa, Akira Koarai, Hisatoshi Sugiura, Tomohiro Ichikawa, Masae Kanda, Rie Tanaka, Keiichiro Akamatsu, Tsunahiko Hirano, Kazuto Matsunaga, Yoshiaki Minakata and Masakazu Ichinose*

Address: Third Department of Internal Medicine, Wakayama Medical University, School of Medicine, Wakayama, Japan

Email: Satoru Yanagisawa - yngsw@wakayama-med.ac.jp; Akira Koarai - koarai@wakayama-med.ac.jp; Hisatoshi Sugiura - sugiura@wakayamamed.ac.jp; Tomohiro Ichikawa - 1kawa@wakayama-med.ac.jp; Masae Kanda - k97025@yahoo.co.jp; Rie Tanaka - rie-t@wakayama-med.ac.jp; Keiichiro Akamatsu - akamatsu@wakayama-med.ac.jp; Tsunahiko Hirano - tsuna@wakayama-med.ac.jp; Kazuto Matsunaga - kazmatsu@wakayama-med.ac.jp; Yoshiaki Minakata - minakaty@wakayama-med.ac.jp;

Masakazu Ichinose* - masakazu@wakayama-med.ac.jp

* Corresponding author

Published: 15 June 2009

Respiratory Research 2009, 10:50 doi:10.1186/1465-9921-10-50
Received: 10 January 2009

Accepted: 15 June 2009

This article is available from: http://respiratory-research.com/content/10/1/50

(c) 2009 Yanagisawa et al; licensee BioMed Central Ltd.

This is an Open Access article distributed under the terms of the Creative Commons Attribution License (http://creativecommons.org/licenses/by/2.0), which permits unrestricted use, distribution, and reproduction in any medium, provided the original work is properly cited.

\begin{abstract}
Background: Excessive oxidative stress has been reported to be generated in inflamed tissues and contribute to the pathogenesis of inflammatory lung diseases, exacerbations of which induced by viral infections are associated with toll-like receptor (TLR) activation. Among these receptors, TLR8 has been reported as a key receptor that recognizes single-strand RNA virus. However, it remains unknown whether TLR8 signaling is potentiated by oxidative stress. The aim of this study is to examine whether oxidative stress modulates TLR8 signaling in vitro.
\end{abstract}

Methods: Human peripheral blood neutrophils were obtained from healthy non-smokers and stimulated with TLR 7/8 agonist imidazoquinoline resiquimod (R848) in the presence or absence of hydrogen peroxide $\left(\mathrm{H}_{2} \mathrm{O}_{2}\right)$. Neutrophilic responses including cytokine release, superoxide production and chemotaxis were examined, and the signal transduction was also analyzed.

Results: Activation of TLR8, but not TLR7, augmented IL-8 release. The R848-augmented IL-8 release was significantly potentiated by pretreatment with $\mathrm{H}_{2} \mathrm{O}_{2}(\mathrm{p}<0.0 \mathrm{I})$, and $\mathrm{N}$-acetyl-L-cysteine reversed this potentiation. The combination of $\mathrm{H}_{2} \mathrm{O}_{2}$ and R848 significantly potentiated NF-kB phosphorylation and IkB $\alpha$ degradation. The $\mathrm{H}_{2} \mathrm{O}_{2}$-potentiated IL-8 release was suppressed by MG132, a proteosome inhibitor, and by dexamethasone. The expressions of TLR8, myeloid differentiation primary response gene 88 (MyD88), and tumor necrosis factor receptor-associated factor 6 (TRAF6) were not affected by $\mathrm{H}_{2} \mathrm{O}_{2}$.

Conclusion: TLR8-mediated neutrophilic responses were markedly potentiated by oxidative stress, and the potentiation was mediated by enhanced NF-kB activation. These results suggest that oxidative stress might potentiate the neutrophilic inflammation during viral infection. 


\section{Introduction}

Reactive oxygen species (ROS) such as hydrogen peroxide $\left(\mathrm{H}_{2} \mathrm{O}_{2}\right)$ and superoxide anion are generated in inflamed tissues and are reported to contribute to the pathogenesis of inflammatory lung diseases including chronic obstructive pulmonary diseases (COPD) $[1,2]$, bronchial asthma $[3,4]$, cystic fibrosis $[5,6]$, and idiopathic pulmonary fibrosis $[7,8]$. Large amounts of ROS derived from inflammatory cells cause pro-inflammatory cytokine production. In fact, $\mathrm{H}_{2} \mathrm{O}_{2}$ has been reported to augment cytokine production in previous studies $[9,10]$. Among inflammatory cells, neutrophils are a key player in the inflammatory lung diseases. It is well-known that excessive infiltration of neutrophils is observed in the airways during exacerbations induced by viral infections [11-14].

Toll-like receptors (TLRs) are simple pattern recognition receptor systems and are known to react with conserved molecular patterns of pathogens [15]. The innate immunity cells also act against viral infections through TLRs including TLR3, TLR7 and TLR8. Human neutrophils possess all functional TLRs except TLR3 [16], and their agonists enhance neutrophil functions such as cytokine release, superoxide generation and phagocytosis [16]. TLR7 and TLR8, located in the endosome, act as anti-viral receptors for recognizing single strand RNA (ssRNA) [1719], which is present at various phases of viral infection from viral entry to replication. After TLR7 and TLR8 are activated by ssRNA, their signals are transduced through myeloid differentiation primary response gene 88 (MyD88 ) and tumor necrosis factor (TNF) receptor-associated factor 6 (TRAF6) leading to enhanced nuclear factorkappa B (NF-kB) DNA binding activity [20]. Activation of NF-kB leads to increased inflammatory gene products such as interleukin-8 (IL-8) and GM-CSF causing neutrophilic inflammation during viral infection. Resiquimod (R848), a potent synthetic agonist of TLR 7/8 has been reported to simulate the effects of ssRNA viruses on TLR $7 / 8$, to prime human neutrophils $[16,21]$, and then increase the biosynthesis of lipid mediators through NF$\mathrm{kB}$ activation [22] suggesting that TLR7 and TLR8 activation might affect the neutrophilic responses.

Although excessive oxidative stress occurs in the airways of inflammatory lung diseases during exacerbations, it remains unclear whether oxidative stress potentiates the neutrophilic responses against viral infection. Therefore, by using human peripheral neutrophils from healthy never-smoking subjects, the present study was designed to clarify whether oxidative stress can potentiate the TLR8mediated neutrophilic responses, including cytokine production, chemotaxis and superoxide generation. Furthermore, we also investigated what signal transductions are associated with this potentiation of the neutrophilic responses.

\section{Materials and methods \\ Reagents}

Commercially available reagents were obtained as follows: Mono-Poly Resolving Medium was from Dainippon Pharmaceutical Co. Ltd. (Osaka, Japan); fetal calf serum (FCS) and RPMI medium 1640 (RPMI 1640) were from Invitrogen (Carlsbad, California, USA); R848 (resiquimod: 4-amino-2-etoxymethyl- $\alpha, \alpha$-dimethyl- $1 H$-imidazo [4,5-c]quinolin-1-ethanol), bafilomycin and 12-o-tetradecanoylphorbol 13-acetate were from Alexis Biochemicals (San Diego, California, USA); R837 (Imiquimod: 1isobutyl-1H-imidazo [4,5-c]quinolin-4-amine) was from Biomol (Plymouth Meeting, Pennsylvania, USA); N-acethyl-L-cysteine, MG-132, dexamethasone and anti- $\beta$-actin antibody were from Sigma (St. Louis, Missouri, USA); anti-TLR8 rabbit polyclonal antibody was from Abgent (San Diego, California, USA); Cellfix solution was from Becton Dickinson (San Jose, California, USA); phycoerythrin (PE)- conjugated anti-TLR8 antibody solution was from Imgenex (San Diego, California, USA); dihydrorhodamine-123 (DHR-123) was from Cayman Chemical (Ann Arbor, Michigan, USA); human recombinant IL-8 was from Acris antibodies (Hiddenhausen, Germany); anti-human MyD88 antibody, anti-human TRAF6, and anti-human IkB $\alpha$ were from Santa Cruz (San Diego, California, USA); peroxidase-conjugated secondary antibodies were from Rockland Immunochemicals (Gilbertsville, Pennsylvania, USA)

\section{Isolation of peripheral blood neutrophils}

Healthy subjects participated in the present study. They were never-smokers and had had no infection for 4 weeks preceding the study. Human peripheral blood neutrophils were isolated from whole blood by a density gradient technique using Mono-Poly Resolving Medium as previously reported [23]. Briefly, whole blood was collected by vein puncture into tubes containing EDTA anticoagulant. Then, each blood sample was gently mounted onto the same volume of Mono-Poly Resolving Medium without mixing. The samples were centrifuged at $400 \times g$ for 20 min at room temperature. The blood was separated into four layers from the top, plasma, lymphocytes/mononuclear cells, neutrophils, and red blood cells. The neutrophil layer was gently collected by a pasteur pipette without aspirating the other layers and put into fresh 20 $\mathrm{ml}$ tubes. This procedure allowed us to obtain neutrophils with over $95 \%$ purity and viability as determined by trypan blue staining. After washing by phosphate-buffered saline (PBS) solution and counting the cell numbers, neutrophils were suspended in 10\% FCS in RPMI 1640 at a concentration of $1 \times 10^{6} \mathrm{cells} / \mathrm{ml}$. The neutrophils were isolated before each experiment and used immediately. All replicate experiments in the current study were performed by using neutrophils from different donors. This study was approved by the local ethics committee of 
Wakayama Medical University School of Medicine. Informed written consent was obtained from all subjects.

\section{Immunocytochemistory}

$100 \mu \mathrm{l}$ of the neutrophil suspension containing $1 \times 10^{5}$ cells were centrifuged by a Cytospin 4 cytocentrifuge (ThermoShandon, ThermoBioAnalysis, Tokyo, Japan) at $25 \times \mathrm{g}$ for $5 \mathrm{~min}$. The preparation was fixed in $4 \%$ paraformaldehyde fixative solution for $30 \mathrm{~min}$. Endogeneous peroxidase activity was blocked by incubation in $0.3 \%$ $\mathrm{H}_{2} \mathrm{O}_{2}$ in PBS for 15 min at room temperature. After washing, the cells were incubated with anti-TLR8 rabbit polyclonal antibody (1:100 dilution) for $12 \mathrm{hrs}$ at $4^{\circ} \mathrm{C}$. Nonspecific binding to the antibody was prevented by preincubation with $2 \%$ bovine serum albumin in PBS containing $0.3 \%$ Triton-X for $30 \mathrm{~min}$. The immunoreactions were visualized by the indirect immunoperoxidase method using Envision polymer reagent, which is goat anti-rabbit IgG conjugated with peroxidase labeled dextran (Dako Japan Ltd, Kyoto, Japan), for 1 hour at room temperature. Diaminobenzidine reaction was performed, followed by counterstaining with hematoxirin. The slides were viewed with a microscope (BX-50, Olympus Corporation, Tokyo, Japan) and photographed with a digital camera (c-5050, Olympus Corporation, Tokyo, Japan).

\section{Flow cytometry analysis}

The expression of TLR8 in neutrophils was assessed by a FACS calibur flow cytometer (Becton Dickinson, San Jose, CA) according to the manufacturer's instructions. Briefly, $200 \mu \mathrm{l}$ of the neutrophil suspension containing $2 \times 10^{6}$ neutrophils were first permeabilized by $1 \times$ permeabilizing solution (Becton Dickinson, San Jose, California, USA) for $30 \mathrm{~min}$ on ice to stain not only cell surface TLR8 but also endosomal TLR8, and then incubated with $4 \mu \mathrm{l}$ of PE-conjugated anti-TLR8 antibody solution or its isotypecontrol for $20 \mathrm{~min}$ at $4^{\circ} \mathrm{C}$. After washing, the samples were fixed by $500 \mu \mathrm{l}$ of $1 \%$ paraformaldehyde for $10 \mathrm{~min}$. Binding of each antibody was detected using CellQuest analysis software on a FACS Calibur (Becton Dickinson, San Jose, California, USA). Specific binding of each antibody was expressed as relative fluorescence that was calculated by the ratio of the mean fluorescence intensity for TLR8 to the mean fluorescence intensity for the isotype control.

\section{TLR stimulation}

Isolated neutrophils were stimulated in 24-well tissue culture plates with various concentrations of R848, a ligand for TLR 7/8, or R837, a ligand for TLR7, for $24 \mathrm{hr}$ at $37^{\circ} \mathrm{C}$ in a humidified atmosphere of $5 \% \mathrm{CO}_{2}$. Cells were pretreated with various concentrations of $\mathrm{H}_{2} \mathrm{O}_{2}$ for $30 \mathrm{~min}$ prior to the stimulation with R848 [24]. To investigate the effects of the inhibitors or a scavenger on the IL- 8 release, cells were further pretreated with each agent prior to the treatment with $\mathrm{H}_{2} \mathrm{O}_{2}$ as follows: bafilomycin, an inhibitor of endosomal acidification, for $15 \mathrm{~min}$; N-acethyl-Lcysteine was for $10 \mathrm{~min}$; MG-132, a proteosome inhibitor, for $60 \mathrm{~min}$; and dexamethasone for $30 \mathrm{~min}$. Media were harvested at 24 hours after treatment with R848 for subsequent enzyme-linked immunosorbent assays (ELISA) to measure various cytokine levels. Similarly, cells were harvested at the same time for flow-cytometry analysis, or western blotting.

\section{Measurement of cytokines}

IL-8 expression was measured by sandwich ELISA (R\&D System Europe, Abingdon, UK) according to the manufacturer's instructions. The lower detection limit was $16 \mathrm{pg} /$ $\mathrm{ml}$. The levels of IL-1 $\beta$, IL-6, IL-10, IL-12 and TNF- $\alpha$ were measured by a Human Inflammation Cytokine Beads array kit (Becton Dickinson, San Jose, California, USA) according to the manufacturer's instructions.

\section{Measurement of superoxide generation}

Neutrophils were pre-incubated with or without $50 \mu \mathrm{M}$ $\mathrm{H}_{2} \mathrm{O}_{2}$, and then stimulated with various concentrations of R848 for $1 \mathrm{hr}$ at $37^{\circ} \mathrm{C}$. Cells were harvested, washed twice and resuspended in 10\% FCS in RPMI 1640 at a concentration of $1 \times 10^{6}$ cells $/ \mathrm{ml}$. One $\mathrm{ml}$ cell suspensions were cultured at $37^{\circ} \mathrm{C}$ with $3 \mu \mathrm{M}$ DHR-123 for $5 \mathrm{~min}$ and then with 12-o-tetradecanoylphorbol 13 -acetate for $30 \mathrm{~min}$ at $37^{\circ} \mathrm{C}$. The cells were cooled on ice, centrifuged, and resuspended in PBS. Stained cells were assessed by a flowcytometer (Becton Dickinson, San Jose, California, USA). The amount of superoxide generation was evaluated by the relative fluorescence intensity of DHR-123 compared with that of the control group.

\section{Chemotaxis assay}

Neutrophils were pre-incubated with or without $50 \mu \mathrm{M}$ $\mathrm{H}_{2} \mathrm{O}_{2}$ and then stimulated with various concentrations of R848 for $1 \mathrm{hr}$. Cells were harvested, washed twice and resuspended in 10\% FCS in RPMI 1640 at a concentration of $2 \times 10^{6}$ cells $/ \mathrm{ml}$. Chemotaxis assays were performed on plastic chemotaxis chambers (pore size: $3 \mu \mathrm{m}$; Kurabou, Osaka, Japan) according to the manufacturer's instructions. Briefly, $250 \mu \mathrm{l}$ of RPMI 1640 containing IL-8 (0.3 $\mathrm{ng} / \mathrm{ml}$ ) were placed into the bottom wells and $100 \mu \mathrm{l}$ of the neutrophil suspension were added into the top wells. The chambers were then incubated in a tissue-culture incubator at $37^{\circ} \mathrm{C}$ for $1 \mathrm{hr}$. The numbers of neutrophils that transmigrated to the bottom wells were counted using a flow-cytometer (Becton Dickinson, San Jose, California, USA). Results are shown as the ratio of the migrated cell number of each group to that of the control group. 


\section{Elastase assay}

Elastase release from the neutrophils was measured by a human PMN elastase ELISA kit (Bender Medsystems, Vienna, Austria) according to the manufacturer's instructions.

\section{Phosflow analysis of phosphorylated NF-kB p65}

$1 \times 10^{6}$ neutrophils were incubated with or without $50 \mu \mathrm{M}$ $\mathrm{H}_{2} \mathrm{O}_{2}$ and stimulated with various concentrations of $\mathrm{R} 848$ for $1 \mathrm{hr}$. The phosphorylated NF-kB p65 levels were measured by the BD phosflow method (Becton Dickinson, San Jose, CA) according to the manufacturer's instructions.

\section{Western blotting}

After stimulation, the neutrophils were centrifuged at 400 $\times \mathrm{g}$ for 10 seconds and incubated on ice for $30 \mathrm{~min}$ with cold Triton buffer (1\% Triton X-100, $150 \mathrm{mM} \mathrm{NaCl}, 20$ $\mathrm{mM}$ Tris-HCl, $\mathrm{pH}$ 7.4, $1 \mathrm{mM}$ EDTA, $2 \mathrm{mM}$ diisopropylfluorophosphate, $5 \mu \mathrm{g} / \mathrm{ml}$ pepstatin A and $1 \mathrm{mM}$ phenylmethylsulfonylfluoride). Then, the cell lysates were centrifuged at $12,000 \times \mathrm{g}$ for $10 \mathrm{~min}$, collected and stored at $-80^{\circ} \mathrm{C}$. Cell lysates were mixed with the same volume of $2 \times$ SDS loading buffer and separated with $12.5 \%$ gradient polyacrylamide gel (DRC Co. Ltd., Tokyo, Japan). After electrophoresis, the proteins were transferred to a nitrocellulose membrane and incubated with anti-human MyD88 antibody (1:200 dilution), anti-human TRAF6 (1:200 dilution), or anti-human IkB $\alpha$ (1:200 dilution) overnight. To standardize the expression of each protein, the membranes were stripped off and re-probed with anti- $\beta$-actin antibody (1:10000 dilution). The membranes were then incubated with the appropriate peroxidase-conjugated secondary antibodies (1:2000 dilution). The bound antibodies were visualized with an ECL-plus detection system (Amersham, Backinghamshire, UK) and photographed by an ECL minicamera (Amersham, Backinghamshire, UK).

\section{Stastical analysis}

Data are expressed as mean values \pm SEM. Data were analyzed by one way analysis of variance (ANOVA) followed by Bonferroni's test or Sheffe's test to adjust for multiple comparisons. An unpaired two-tailed Student's t-test was used for single comparisons. Probability values of less than 0.05 were considered significant.

\section{Results}

\section{Detection of toll-like receptor (TLR) 8 in human} polymorphonuclear cells (PMNs) and its reaction to $\mathbf{R} 848$ To determine whether human neutrophils express TLR8, we first investigated the expression of TLR8 in neutrophils by immunocytochemistry and flow-cytometry. As shown in Figure 1A, TLR8 was detected by immunocytochemistry. To examine the cellular localization of TLR8, we performed flow-cytometry analysis against TLR8. TLR8 was stained with or without cell membrane permeabilization, indicating that TLR8 exists not only in the cytosol such as the endosome but also on the cell surface (Figure 1B).

We next investigated the effect of TLR7 ligand R837 or TLR $7 / 8$ ligand R848 on the release of IL- 8 from neutrophils. R848 increased IL- 8 release in a time-dependent manner (Figure 1C). As shown in figure 1D, R848 dose-dependently augmented the release of IL- 8 at 24 hr, whereas R837 had no effect. To confirm whether this augmentation of IL-8 release is mediated by TLR signaling, the cells were pretreated with bafilomycin, an inhibitor of endosomal acidification. Pretreatment with bafilomycin significantly inhibited the R848-augmented IL-8 release in a dosedependent manner (Figure 1E). Dexamethasone also significantly inhibited the R848-augmented IL-8 release (Figure $1 \mathrm{~F})$.

\section{Effect of $\mathrm{H}_{2} \mathrm{O}_{2}$ on $\mathrm{R} 848$-augmented cytokine release, superoxide generation, elastase release, and chemotaxis in human PMNs}

To examine whether oxidative stress potentiates the R848augmented IL-8 release, we examined the effects of $\mathrm{H}_{2} \mathrm{O}_{2}$ on the IL- 8 release from neutrophils. Pretreatment with $\mathrm{H}_{2} \mathrm{O}_{2}$ significantly potentiated the R848-augmented IL-8 release in a dose-dependent manner (Figure 2A). Preincubation with $50 \mu \mathrm{M} \mathrm{H}_{2} \mathrm{O}_{2}$ shifted the dose-response curve leftward ( $\log \mathrm{EC}_{50} 2.757$ vs. $1.775 \mu \mathrm{M}, \mathrm{p}<0.01$, Figure $2 \mathrm{~B}$ ). In addition, the maximal response by $\mathrm{R} 848$ was also significantly potentiated compared with control (Figure $2 \mathrm{~B}$ ). This potentiation was abolished by an antioxidant, N-acetyl-L-cysteine, compared with the vehiclepretreatment group (Figure 2C). The effect of R848 on the release of cytokines and the potentiation by $\mathrm{H}_{2} \mathrm{O}_{2}$ were also examined. As shown in Figure 2D-F, R848 significantly augmented TNF- $\alpha$, IL- 6 and IL- $1 \beta$ release from neutrophils. $\mathrm{H}_{2} \mathrm{O}_{2}$ potentiated the R848-augmented TNF- $\alpha$ (Figure 2D) and IL-6 release (Figure 2E) as well as IL-8, but $\mathrm{H}_{2} \mathrm{O}_{2}$ caused no potentiation of the IL- $1 \beta$ release (Figure $2 \mathrm{~F}$ ). Furthermore, we investigated whether $\mathrm{H}_{2} \mathrm{O}_{2}$ potentiated the R848-induced neutrophilic responses, including superoxide generation, elastase release, and chemotaxis. Neither $\mathrm{H}_{2} \mathrm{O}_{2}$ nor R848 stimulated superoxide production on their own, but the combination of the two did (Figure 3A), whereas $\mathrm{H}_{2} \mathrm{O}_{2}$ did not cause any potentiation of the elastase release and chemotactic capacity (Figure 3B and 3C).

\section{Effect of $\mathrm{H}_{2} \mathrm{O}_{2}$ on the R848-mediated TLR8 signaling}

To clarify the mechanisms of the potentiation of the R848-induced neutrophilic responses by $\mathrm{H}_{2} \mathrm{O}_{2}$, we investigated whether $\mathrm{H}_{2} \mathrm{O}_{2}$ modulates the NF-kB activation induced by $\mathrm{R} 848$, which is a key signaling in TLR activation. Although $\mathrm{R} 848$ or $\mathrm{H}_{2} \mathrm{O}_{2}$ enhanced the phosphorylation of NF-kB p65, the phosphorylation was significantly augmented by the combination of $\mathrm{R} 848$ and $\mathrm{H}_{2} \mathrm{O}_{2}$ (Figure 
(A)
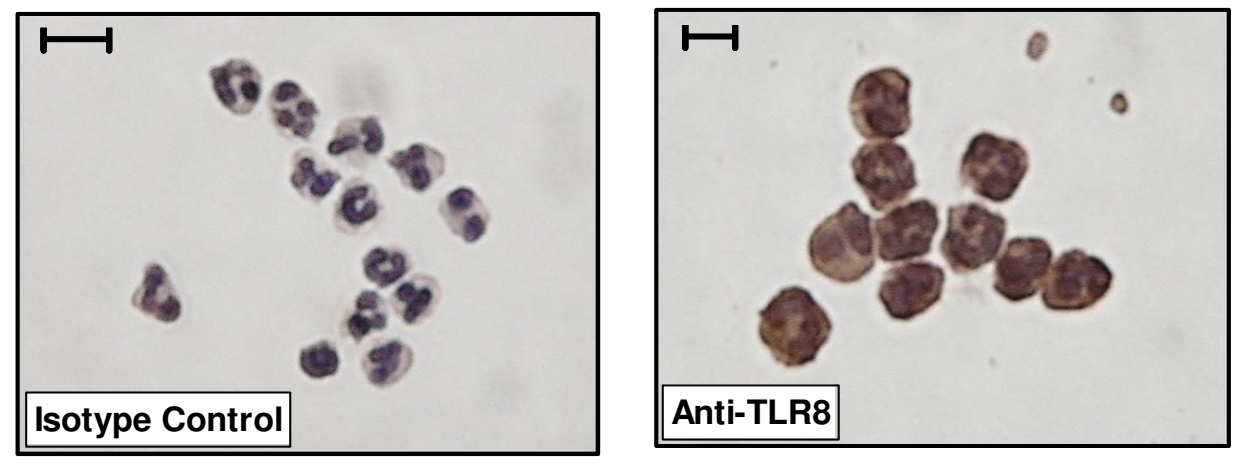

(B)

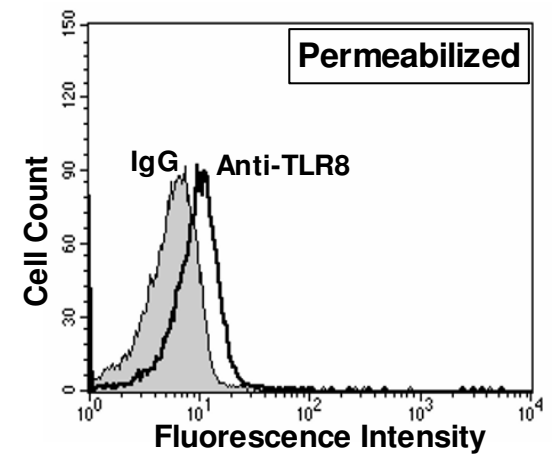

(C)

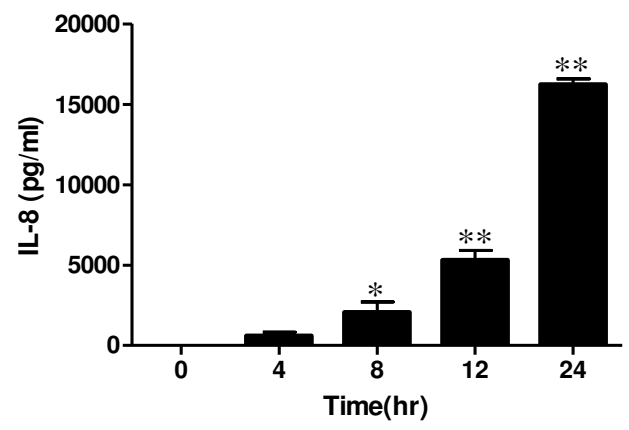

(E)

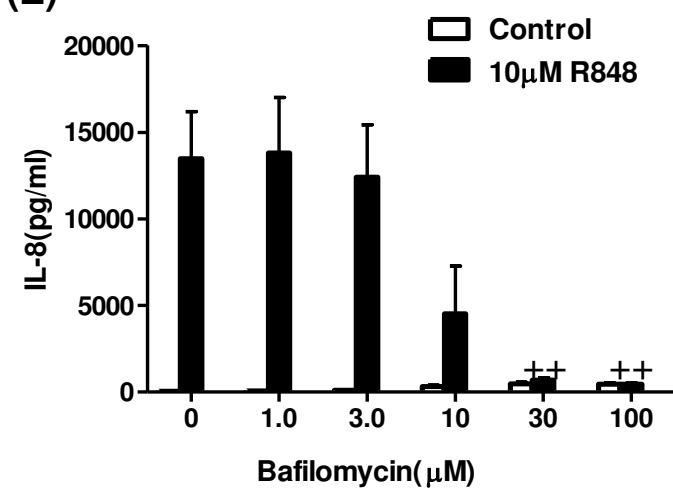

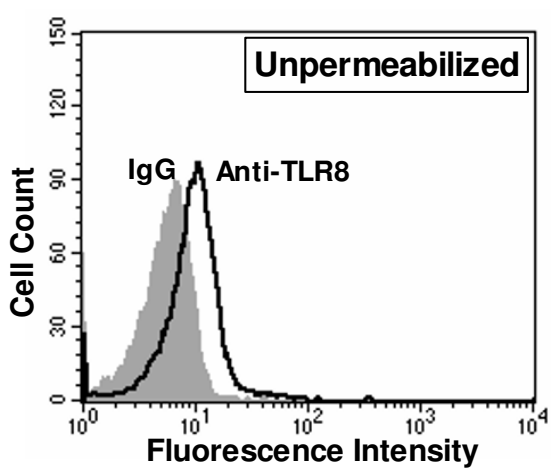

(D)

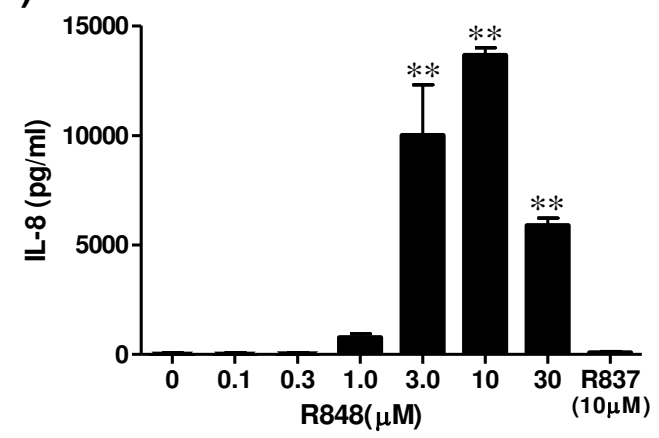

(F)

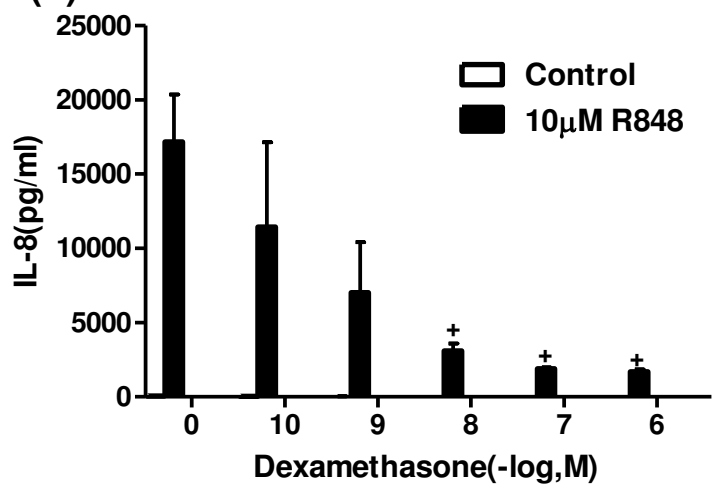

Figure I (see legend on next page) 
Figure I (see previous page)

Detection of toll-like receptor (TLR) 8 in human polymorphonuclear cells (PMNs), and the effects of TLR 7/8 ligand $\mathbf{R 8 4 8}$ on interleukin(IL)-8 release. (A) TLR8 in PMN was detected by immunocytochemistry. Left panel indicates isotype control. Right panel shows TLR8 immunoreactivity in PMN. (Original magnification: $\times 400$, Scale bars $=10 \mu \mathrm{m}$ ). $(\mathrm{B})$ TLR8 expression was analyzed by flow-cytometry. PMNs were stained by anti-human TLR8 (solid lines) or the isotype control (gray histograms) in the permeabilized (left panel) and unpermeabilized condition (right panel). Left panel indicates both intercellular and cell surface expression of TLR8. Right panel shows cell surface expression alone. (C-F) Effect of R848 on the release of IL-8, and effect of bafilomycin or dexamethasone on the R848-induced IL-8 release from PMN. (C) PMNs were treated with $10 \mu \mathrm{M}$ R848. The media were harvested at various time points and assayed for IL-8 by ELISA. (D) PMNs were treated for $24 \mathrm{hrs}$ with R837, a ligand of TLR7, or various concentrations of R848, a ligand of TLR 7/8. Media were assayed for IL-8 by ELISA. (E, F) PMNs were treated with $10 \mu \mathrm{M}$ R848 or vehicle in the presence of various concentrations of bafilomycin, an inhibitor of endosomal acidification (E), or dexamethasone (F). Media were assayed for IL-8 by ELISA. All values are mean values \pm SEM of three to four separate experiments. ${ }^{*} p<0.05$, ${ }^{* *} p<0.01$, compared with the values of control; $+p<0.05,++p$ $<0.0 \mathrm{I}$, compared with the values of the vehicle-pretreated and $10 \mu \mathrm{M}$ R848-treated group.

4A). To investigate the mechanisms in the enhancement of NF-kB p65 phosphorylation by $\mathrm{H}_{2} \mathrm{O}_{2}$, we examined the effect of $\mathrm{H}_{2} \mathrm{O}_{2}$ on IkB $\alpha$ expression in the presence of $\mathrm{R} 848$. As shown in Figure 4B, R848 treatment dose-dependently reduced the IkB $\alpha$ protein levels. Furthermore, $50 \mu \mathrm{M}$ $\mathrm{H}_{2} \mathrm{O}_{2}$ significantly reduced the IkB $\alpha$ protein level in the R848-treated cells, suggesting that $\mathrm{H}_{2} \mathrm{O}_{2}$ could modulate the NF-kB activity through the regulation of IkB $\alpha$ expression. Because NF-kB regulates IL-8 gene expression, we examined the effect of MG-132, a proteosome inhibitor, on the IL-8 release in the presence of $\mathrm{R} 848$ and $\mathrm{H}_{2} \mathrm{O}_{2}$. Pretreatment with MG-132 dose-dependently inhibited IkB $\alpha$ degradation as estimated by western blotting (Additional file 1). MG-132 also significantly reduced the augmented IL-8 release by treatment with $\mathrm{R} 848$ and $\mathrm{H}_{2} \mathrm{O}_{2}$ (Figure 4C). Furthermore, we evaluated whether $\mathrm{H}_{2} \mathrm{O}_{2}$ affected the amounts of TLR8, MyD88 and TRAF6, which are thought to be key molecules in TLR8 signaling. $\mathrm{H}_{2} \mathrm{O}_{2}$ did not affect these protein amounts in the presence of R848 (data not shown).

\section{Effect of dexamethasone on the $\mathrm{H}_{2} \mathrm{O}_{2}$-potentiated IL-8 release}

Because steroids have been used for viral infectioninduced exacerbations of various pulmonary diseases such as bronchial asthma or COPD, we examined the effect of dexamethasone on the $\mathrm{H}_{2} \mathrm{O}_{2}$-potentiated IL-8 release in the R848 treated cells. As shown in Figure 5, dexamethasone dose-dependently reduced the $\mathrm{H}_{2} \mathrm{O}_{2}$ potentiated IL-8 release in the presence of $\mathrm{R} 848$. However, the inhibitory effects of dexamethasone were lower in the $\mathrm{H}_{2} \mathrm{O}_{2}$ and $\mathrm{R} 848$ combination treatment group than in the R848 treatment group.

\section{Discussion}

In the current study, we have shown that peripheral blood neutrophils from healthy never-smoking subjects expressed TLR8, and that the TLR 7/8 ligand R848, but not the TLR7 ligand, induced IL-8 release from neutrophils.
$\mathrm{H}_{2} \mathrm{O}_{2}$ potentiated the R848-augmented IL-8 release, and this potentiation was reversed by $\mathrm{N}$-acetyl-L-cysteine. In addition, $\mathrm{H}_{2} \mathrm{O}_{2}$ potentiated the release of TNF- $\alpha$ and IL- 6 , and the superoxide generation in the R848 treated neutrophils. Although the expressions of TLR8, MyD88 and TRAF6 were not affected by $\mathrm{H}_{2} \mathrm{O}_{2}, \mathrm{H}_{2} \mathrm{O}_{2}$ enhanced the phosphorylation of NF-kB and potentiated the IkB $\alpha$ degradation in the R848 treated cells. Furthermore, MG-132, a proteosome inhibitor, reversed the $\mathrm{H}_{2} \mathrm{O}_{2}$-potentiated IL8 release in the R848 treated neutrophils. These results suggested that oxidative stress potentiated the release of various R848-induced cytokines and superoxide generation in human neutrophils through NF-kB activation.

Previous reports have demonstrated that human peripheral blood neutrophils possessed all known TLRs except TLR3, but the expression levels of TLR7 and its reponses are extremely limited [16]. In the present study, R848, a potent synthetic agonist of TLR 7/8, but not the TLR7 ligand R837, enhanced the neutrophilic responses including the cytokine production (IL- 8 , TNF- $\alpha$, IL- 6 and IL- $1 \beta$ ), the superoxide generation and the chemotaxis of neutrophils. This is consistent with a previous study, which showed that the influenza virus and R848 stimulated the IL-8 release in neutrophils through the activation of TLR $7 / 8$ [21]. It was also shown that TLR7 knockout neutrophils respond poorly to both the TLR 7/8 ligand and the influenza virus in comparison with wild type neutrophils, suggesting that TLR7 plays an essential role in murine neutrophils. These results are inconsistent with our current study. However, several studies have reported that TLR7 stimulation affects the cytokine release not in human neutrophil, but in murine neutrophils $[25,26]$. These results suggest that the discrepancy of the findings with the previous report might be due to differences in the species.

In the current study, we showed that $\mathrm{H}_{2} \mathrm{O}_{2}$ potentiated the cytokine release including IL- 8 , TNF- $\alpha$, and IL- 6 , and the 
(A)

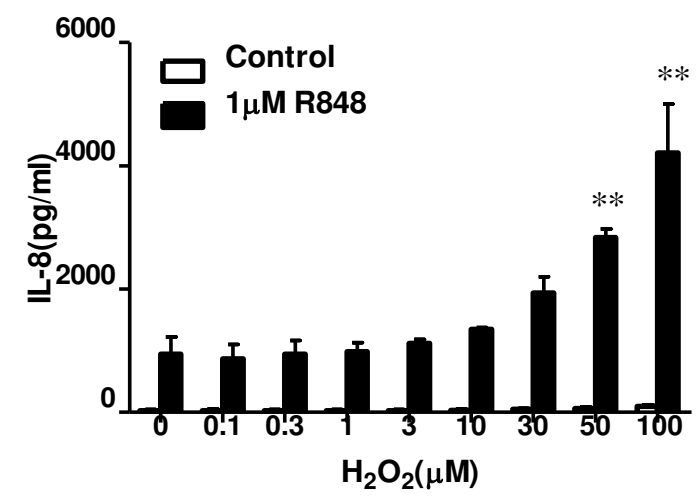

(C)

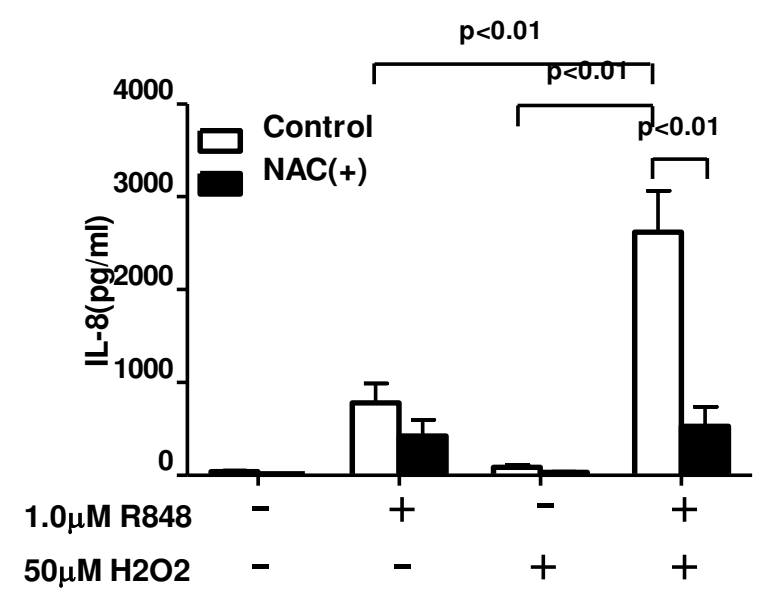

(E)

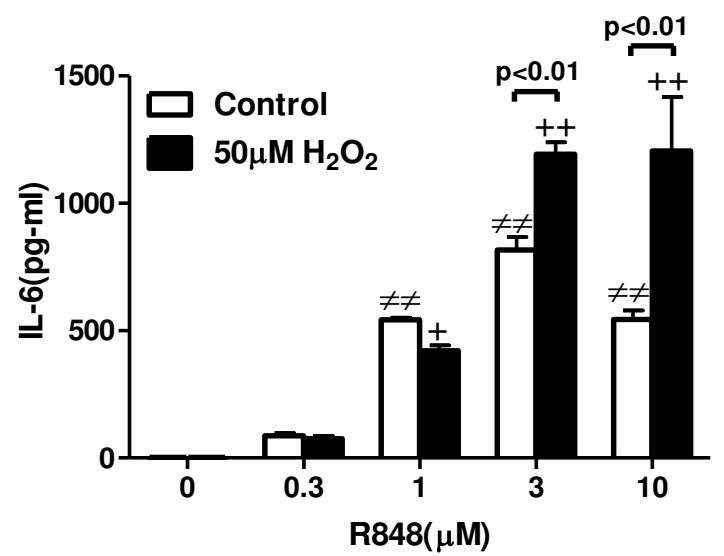

(B)

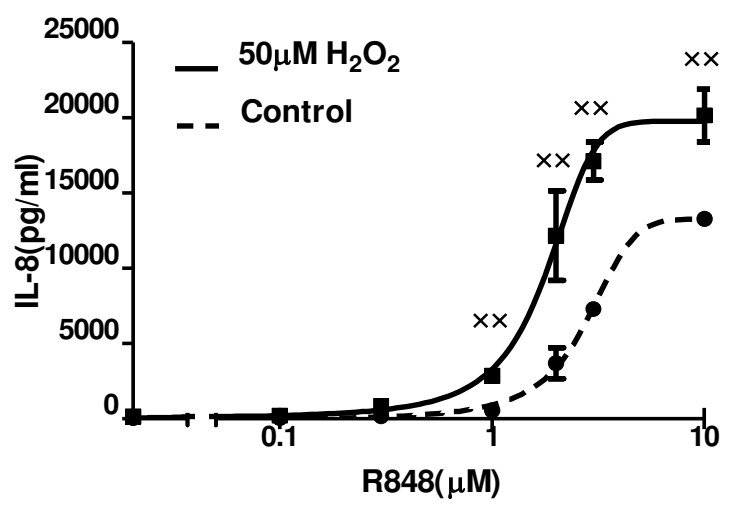

(D)

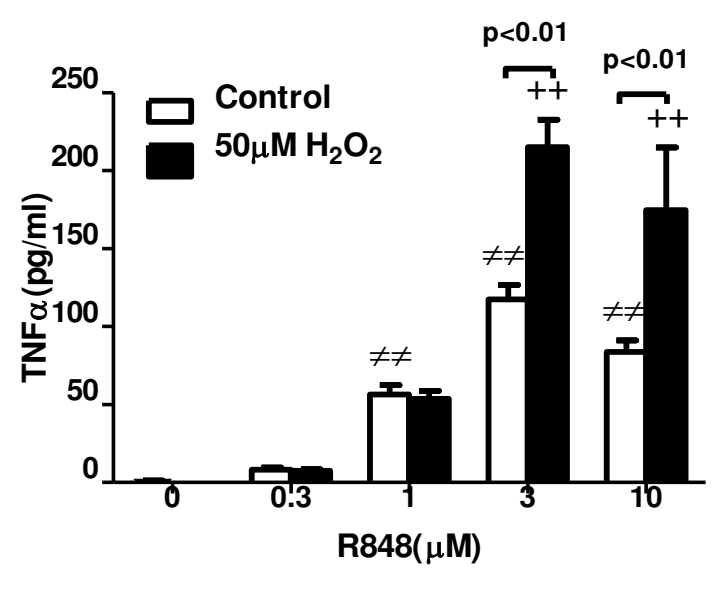

(F)

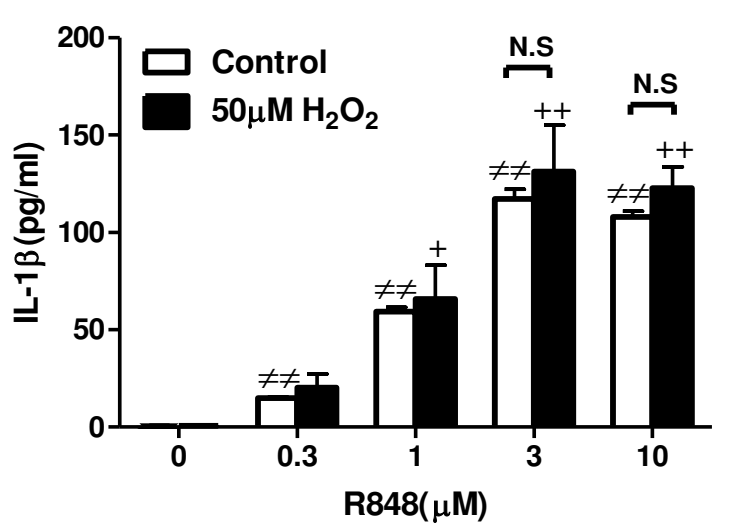

Figure 2 (see legend on next page) 
Figure 2 (see previous page)

Effect of $\mathrm{H}_{2} \mathrm{O}_{2}$ on the R848-induced cytokine release from human PMNs, and effect of $\mathbf{N}$-acethyl-L-cysteine on the potentiation of cytokine release by $\mathbf{H}_{2} \mathbf{O}_{2}$. (A) PMNs were incubated with various concentrations of $\mathrm{H}_{2} \mathrm{O}_{2}$ for 30 min, and then treated with R848 for 24 hrs. Media were assayed for IL-8 by ELISA. (B) Various concentrations of R848 were added to PMNs in the presence or absence of $50 \mu \mathrm{M} \mathrm{H}_{2} \mathrm{O}_{2}$. After $24 \mathrm{hrs}$, IL-8 levels in media were measured by ELISA. Doseresponse curve of IL-8 release from PMNs was plotted against the R848 concentration. (C) Ten mM N-acethyl-L-cysteine (NAC) was added 10 min before $\mathrm{H}_{2} \mathrm{O}_{2}$ or vehicle treatment, then the PMNs were cultured for 24 hrs in the presence or absence of R848. (D-F) Effects of $\mathrm{H}_{2} \mathrm{O}_{2}$ on TNF- $\alpha$ (D), IL-6 (E) and IL-I $\beta$ (F) release from the R848-treated PMNs were assessed by Cytokine-Beads Array. All values are mean values \pm SEM of three to five separate experiments. **p $<0.01$, compared with the values of vehicle-pretreated I $\mu \mathrm{M}$ R848-treated group; ${ }^{\times \times} \mathrm{p}<0.0 \mathrm{I}$, compared with the values of control; $\neq \neq \mathrm{p}<$ $0.0 \mathrm{I}$, compared with the values of vehicle treated group; $+p<0.05,{ }^{++}+\mathrm{p}<0.0 \mathrm{I}$, compared with the values of $50 \mu \mathrm{M} \mathrm{H}_{2} \mathrm{O}_{2}-\mathrm{pre}^{-}$ treated and vehicle-treated group.

superoxide generation in R848-treated neutrophils. In addition, this potentiation was reversed by $\mathrm{N}$-acethyl-Lcysteine suggesting that oxidative stress is associated with the potentiation of the R848-mediated neutrophilic response. A previous report has shown that $\mathrm{H}_{2} \mathrm{O}_{2}$ preincubation potentiated lipopolysaccharide-induced IL-8 production, and that hydroxy radical scavengers markedly suppressed this potentiation $[9,10,27]$. These results are consistent with our findings. Although $\mathrm{H}_{2} \mathrm{O}_{2}$ potentiated the R848-augmented neutrophilic responses, the potentiation seemed to be heterogeneous. Indeed, $\mathrm{H}_{2} \mathrm{O}_{2}$ potentiated the R848-augmented IL-8, TNF- $\alpha$, and IL- 6 release, but did not potentiate the IL- $1 \beta$ release. This was an interesting finding because the degree of oxidative stress may modulate the profile of inflammatory mediators during viral infection. In the current study, it remained unclear why the potentiation by oxidative stress was heterogeneous. A future study is needed to explore this issue.

Hydrogen peroxide enhanced the R848-induced phosphorylation of NF-kB, and potentiated the degradation of IkB $\alpha$. In addition, a proteosome inhibitor, MG-132, inhibited the $\mathrm{H}_{2} \mathrm{O}_{2}$-augmented IL-8 release in the $\mathrm{R} 848$ treated neutrophils. Considering that $\mathrm{H}_{2} \mathrm{O}_{2}$ did not affect the expression levels of TLR8 or other signaling molecules such as MyD88 or TRAF6, these results suggested that the $\mathrm{H}_{2} \mathrm{O}_{2}$-potentiated NF-kB activation could play a central role in the augmentation of the neutrophilic responses. This was consistent with previous reports, which have shown that oxidative stress cooperatively activated NF-kB with other mediators such as TNF- $\alpha$ [28-30].

In Figure $4 \mathrm{~A}$ and $4 \mathrm{~B}$, the phosphorylation of NF-kB p 65 in the vehicle-pretreated and R848-treated group was less than in the $\mathrm{H}_{2} \mathrm{O}_{2}$-pretreated and vehicle-treated group. In theory, the phosphorylation in the vehicle-pretreated and R848-treated group should be greater than in the $\mathrm{H}_{2} \mathrm{O}_{2}$ pretreated and vehicle-treated group. There is a possible explanation for this discrepancy. Generally, NF-kB is phosphorylated by NF-kB kinase and $\operatorname{IkB} \alpha$ kinases when $\mathrm{NF}-\mathrm{kB}$ is dissociated from $\mathrm{IkB} \alpha$ and translocated into the nucleus in various types of cells [31,32]. There is no report that explored the interaction between NF-kB phosphorylation and $\operatorname{IkB} \alpha$ degradation in neutrophils under TLR8 activation. Therefore, the finding observed in the current study may be due to an unknown signaling in the R848treated neutrophils.

Steroids have been reported to reduce the severity and duration of admission in exacerbations of COPD and asthma. In this study, dexamethasone inhibited the R848augmented IL-8 release from neutrophils in a dosedependent manner, and this inhibition was observed in the presence or absence of $\mathrm{H}_{2} \mathrm{O}_{2}$. These results might indicate that steroids are useful therapeutic agents to attenuate the viral-induced neutrophilic inflammation. However, the pretreatment with $\mathrm{H}_{2} \mathrm{O}_{2}$ attenuated the effect of dexamethasone, suggesting that oxidative stress induced the steroid resistance. It has been reported that oxidative stress attenuates the effects of steroids in macrophages and epithelial cells through histone deacetylase 2 inactivation [24,33]. This mechanism may also explain the results observed in the present study.

There are several limitations in the current study. First, we used $\mathrm{H}_{2} \mathrm{O}_{2}$ as a model of oxidative stress. Many previous reports used this in vitro model to mimic the pathophysiological condition of oxidative stress observed in inflammatory lung diseases including COPD and asthma. We used $\mathrm{H}_{2} \mathrm{O}_{2}$ at $0.1-100 \mu \mathrm{M}$ in the current study and these concentrations are the same range as in previous reports $[24,34]$. However, we should be careful when extrapolating the findings obtained in this in vitro model to the "real" pathophysiological conditions in inflammatory lung diseases. Second, we used neutrophils isolated from healthy subjects, not from smokers or patients with lung diseases. According to previous reports, the characteristics of neutrophils are altered in patients with COPD compared with healthy subjects [23,35]. The neutrophilic responses to TLR activation may be altered in patients with inflammatory lung disease. Third, we used R848 as a synthetic ligand for TLR 7/8. Many reports have used R848 
(A)

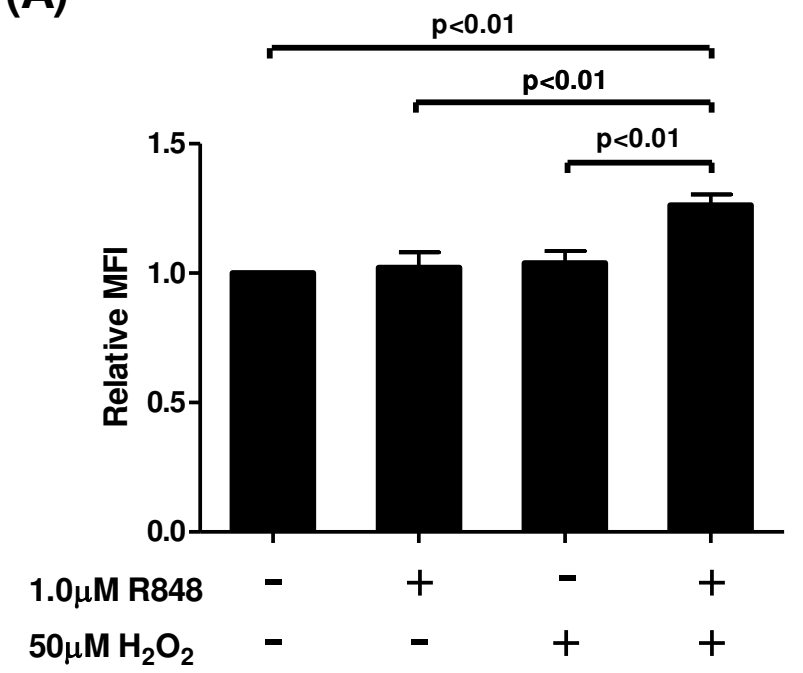

(C)

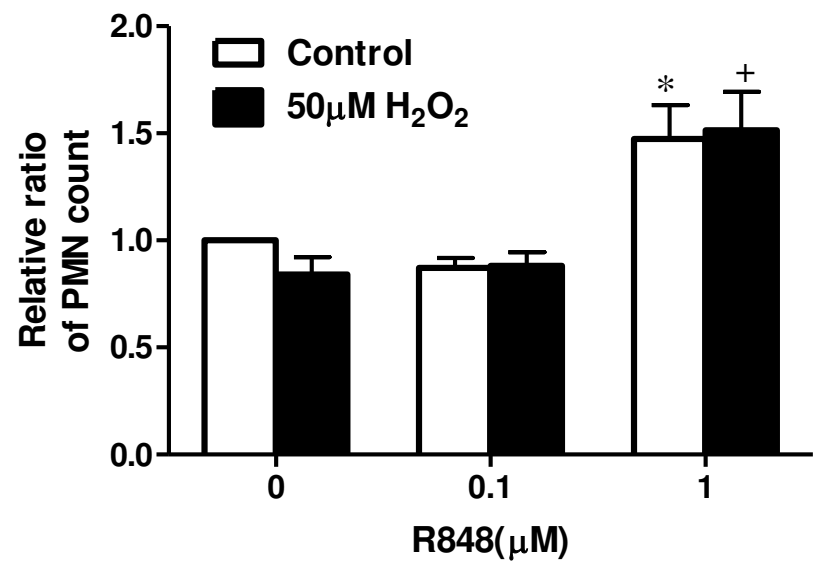

(B)

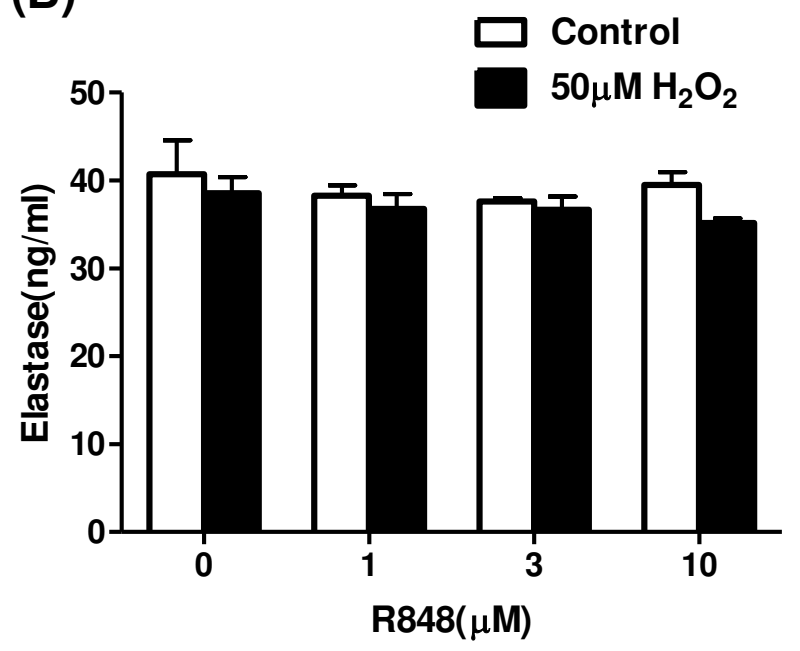

Figure 3

Effect of $\mathrm{H}_{2} \mathrm{O}_{2}$ on the R848-induced superoxide generation, elastase release and chemotaxis in human PMNs. (A) PMNs were preincubated for 30 min with or without $50 \mu \mathrm{M} \mathrm{H}_{2} \mathrm{O}_{2}$, and treated with vehicle or R848. Cells were then harvested and incubated with dihydro-rhodamine-I23 (DHR-I23) for $5 \mathrm{~min}$. The amount of superoxide generation was indicated as the relative fluorescence intensity of DHR-I23. (B) After incubation with or without $50 \mu M \mathrm{H}_{2} \mathrm{O}_{2}, \mathrm{PMNs}$ were stimulated with various concentrations of R848 for $24 \mathrm{hrs}$. The media were assayed for elastase release by ELISA. (C) After one hour treatment with various concentrations of R848 with or without $50 \mu \mathrm{M} \mathrm{H}_{2} \mathrm{O}_{2}$, chemotactic capacity toward IL-8 was assessed by a modified boyden chamber method. Vertical axis: Relative ratio of the PMN counts (-fold increase). Relative ratio of the PMN counts was calculated as the ratio of the migrated cell count of each group to that of the control group. All values are mean values \pm SEM of three to four separate experiments. ${ }^{*} \mathrm{p}<0.05$, compared with the values of vehicle-treated group; $+\mathrm{p}<$ 0.05 , compared with the values of $50 \mu \mathrm{M} \mathrm{H}_{2} \mathrm{O}_{2}$-pretreated and vehicle-treated group; $\mathrm{MFI}=$ mean fluorescence intensity. 
(A)

(B)
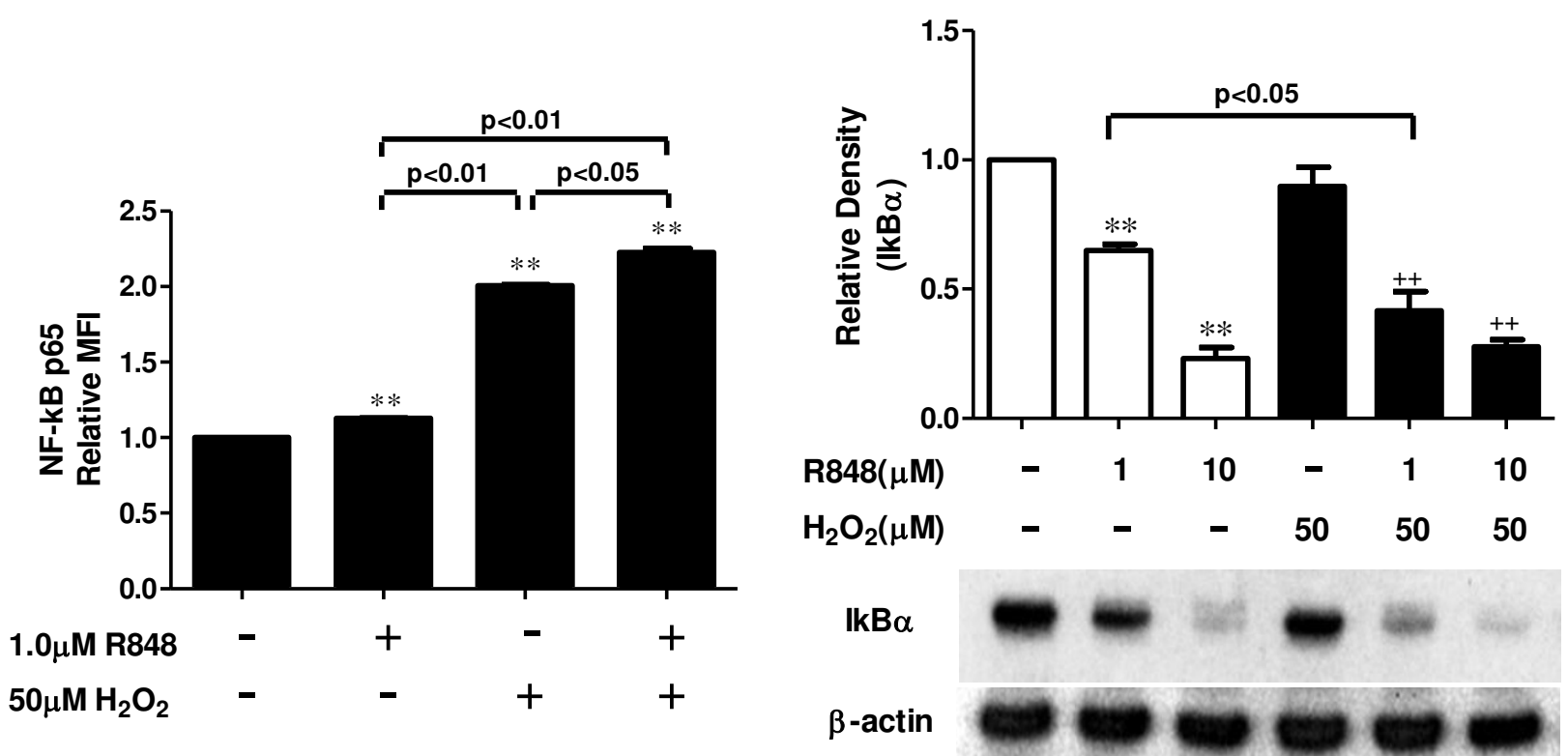

(C)

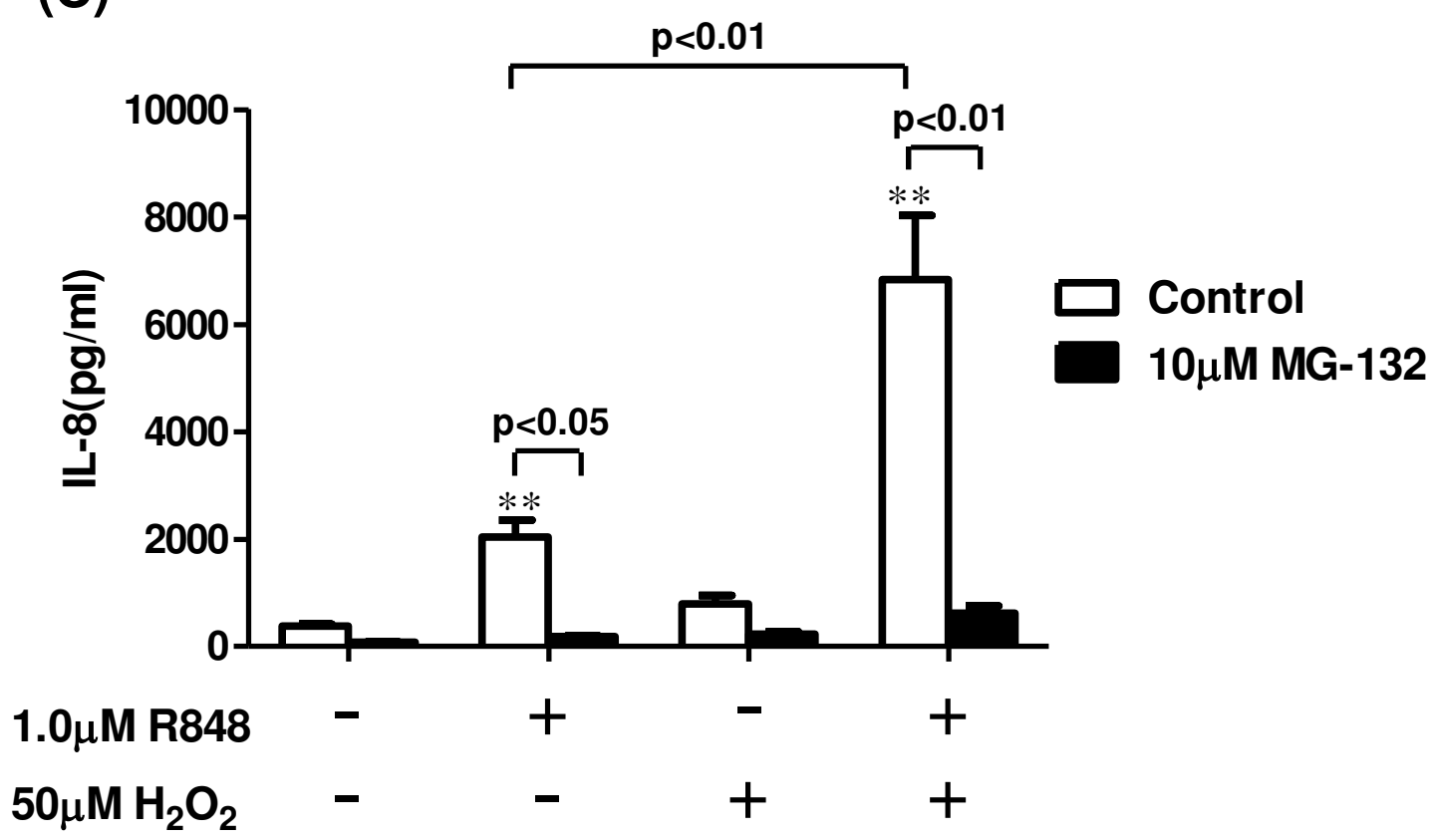

Figure 4 (see legend on next page) 
Figure 4 (see previous page)

Effect of $\mathrm{H}_{2} \mathrm{O}_{2}$ on the R848-induced nuclear factor-kappa B (NF-kB) activation. Cells were treated with or without $50 \mu \mathrm{M} \mathrm{H}_{2} \mathrm{O}_{2}$, and then further treated with various concentrations of R848 for $60 \mathrm{~min}$. Phosphorylated NF-kB p65 was assayed by a flow cytometer $(\mathrm{A})$, and nuclear factor of kappa light polypeptide gene enhancer in B-cells inhibitor, alpha (IkB $\alpha)$ protein levels were assayed by western blotting $(B)$. Each band intensity was assessed by densitometry. Relative intensity was calculated as the ratio of the specific band intensity to that of each appropriate $\beta$-actin band intensity. (C) PMNs were treated with I $\mu M$ R848 with or without $50 \mu \mathrm{M} \mathrm{H}_{2} \mathrm{O}_{2}$ in the presence or absence of MG-I32, a proteosome inhibitor. After 24 hrs, the media were assayed for IL- 8 by ELISA. All values were mean values \pm SEM of three to five separate experiments, and analyzed by ANOVA followed by Bonferroni's test. ${ }^{* *} p<0.01$, compared with the values of control; $++p<0.01$, compared with the values of $\mathrm{H}_{2} \mathrm{O}_{2}$-pretreated and vehicle-treated group; NF-kB p65 = nuclear factor-kappa $\mathrm{B}$ p65; IkB $\alpha=$ nuclear factor of kappa light polypeptide gene enhancer in B-cells inhibitor, alpha.

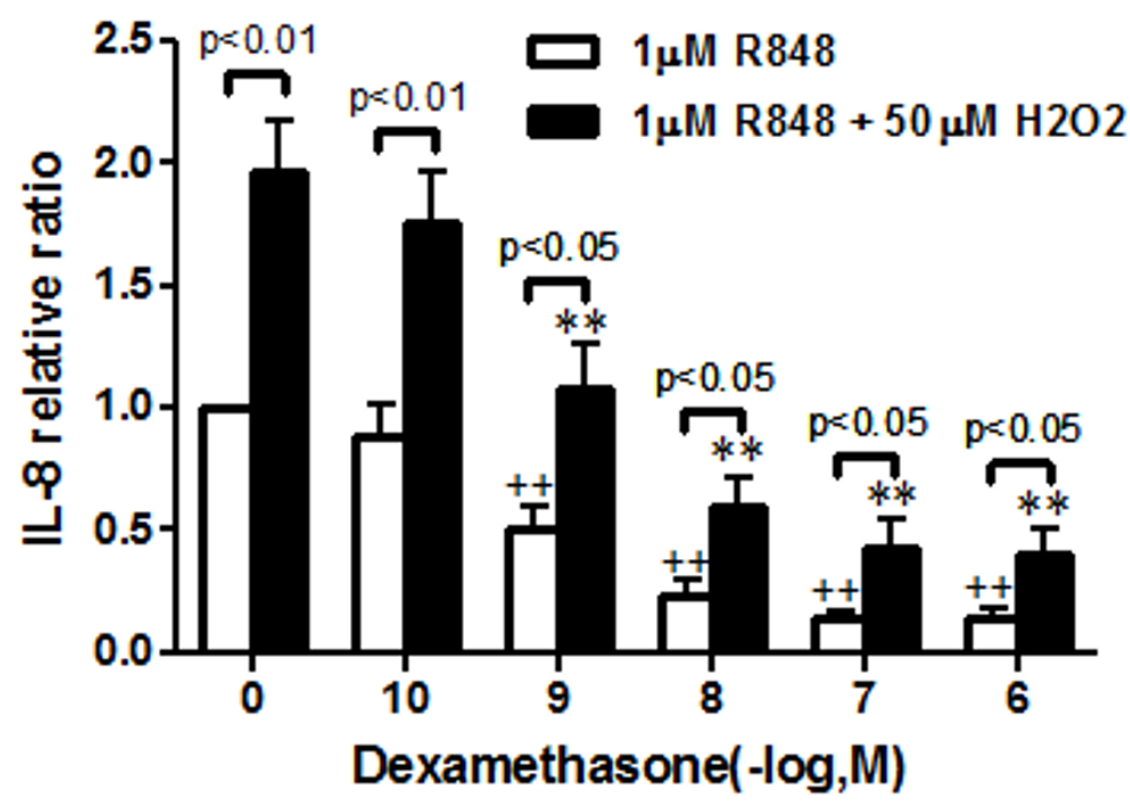

Figure 5

Effect of dexamethasone on the $\mathbf{H}_{2} \mathrm{O}_{2}$-potentiated IL-8 release in the R848-treated PMNs. PMNs were treated with or without dexamethasone for 30 min before treatment with or without $50 \mu M \mathrm{H}_{2} \mathrm{O}_{2}$. Then, cells were treated with R848 for 24 hours. Media were assayed for IL- 8 by ELISA. Vertical axis: IL- 8 relative release (-fold increase). IL- 8 relative ratio was calculated as follows: IL-8 relative ratio $=$ IL- 8 levels in the various conditions/IL- 8 levels in the vehicle-pretreated and R848-treated condition. All values are mean values \pm SEM of six separate experiments. $++p<0.01$, compared with the values of vehicle pretreated R848 treated group; **p < 0.0 I, compared to the values of $\mathrm{H}_{2} \mathrm{O}_{2}$ pretreated R848 treated group. 
as the ligand $[16,21,22]$. The stimulation of TLR $7 / 8$ by R848 might be different from that of single strand RNA virus infection. In the current study, we attempted to elucidate the effects of oxidants on the TLR8 signaling. To accomplish this, we used R848 for the following reasons. First, R848 is a stable agent and is easy to handle compared with single strand RNA. Second, R848 does not have any other effect except TLR 7/8 stimulation. Indeed, the R848 signaling was abolished by treatment with bafilomycin, an inhibitor of endosomal acidification. Therefore, the findings in the current study seemed to be mediated by TLR 8 signaling.

In conclusion, we have shown that the TLR8-mediated neutrophilic responses in healthy never-smoking subjects were markedly potentiated by oxidative stress, and this potentiation was mediated by enhanced NF-kB activation. These results suggested that oxidative stress might potentiate the neutrophilic inflammation during viral infection.

\section{Abbreviations}

COPD: Chronic obstructive pulmonary disease; TLR8: Toll-like receptor $8 ; \mathrm{H}_{2} \mathrm{O}_{2}$ : Hydrogen peroxide; NF-kB p65: Nuclear factor-kappa B p65; IkB $\alpha$ : Nuclear factor of kappa light polypeptide gene enhancer in B-cells inhibitor, alpha; MyD88: Myeloid differentiation primary response gene 88; TRAF6: Tumor necrosis factor receptorassociated factor 6 .

\section{Competing interests}

The authors declare that they have no competing interests.

\section{Authors' contributions}

SY carried out the data analysis and drafted the manuscript. AK, HS, and MI participated in the design of the original study, and contributed substantially to the manuscript. TI, MK, RT, KA, TH, KM and YM assisted with data analysis and interpretation, and supervised statistical analysis.

\section{Additional material}

\section{Additional file 1}

Effect of MG-132 on the R848-induced nuclear factor of kappa light polypeptide gene enhancer in B-cells inhibitor, alpha $(\operatorname{IkB} \alpha)$ degradation. PMNs were incubated with or without $10 \mu \mathrm{MMG}-132$, a proteosome inhibitor, and then further treated with various concentrations of R848 for $60 \mathrm{~min}$. The cytoplasmic fraction of cell lysates were used for estimating the protein levels of IKB $\alpha$ by western blotting. Each band intensity was assessed by densitometry. Relative intensity was calculated as the ratio of specific band intensity to that of each appropriate $\beta$-actin band intensity. All values are mean values \pm SEM of three separate experiments. ${ }^{* *} p<0.01$; compared with the values of vehicle-treated group, $I k B \alpha=$ nuclear factor of kappa light polypeptide gene enhancer in B-cells inhibitor, alpha, n.s. = not significant.

Click here for file

[http://www.biomedcentral.com/content/supplementary/14659921-10-50-S1.pdf]

\section{Acknowledgements}

We acknowledge Mr. Brent Bell for reading this manuscript.

\section{References}

I. MacNee W: Pulmonary and systemic oxidant/antioxidant imbalance in chronic obstructive pulmonary disease. Proc $\mathrm{Am}$ Thorac Soc 2005, 2(I):50-60.

2. Rahman I, Adcock IM: Oxidative stress and redox regulation of lung inflammation in COPD. Eur Respir J 2006, 28(1):2 19-242.

3. Barnes PJ, Chung KF, Page CP: Inflammatory mediators of asthma: an update. Pharmacol Rev 1998, 50(4):515-596.

4. Sugiura $H$, Ichinose $M$ : Oxidative and nitrative stress in bronchial asthma. Antioxid Redox Signal 2008, I 0(4):785-797.

5. Brown RK, Kelly FJ: Evidence for increased oxidative damage in patients with cystic fibrosis. Pediatr Res 1994, 36(4):487-493.

6. Starosta V, Rietschel E, Paul K, Baumann U, Griese M: Oxidative changes of bronchoalveolar proteins in cystic fibrosis. Chest 2006, I 29(2):43 I-437.

7. Cantin AM, North SL, Fells GA, Hubbard RC, Crystal RG: Oxidantmediated epithelial cell injury in idiopathic pulmonary fibrosis. J Clin Invest 1987, 79(6): I665-I673.

8. Kinnula VL, Fattman CL, Tan RJ, Oury TD: Oxidative stress in pulmonary fibrosis: a possible role for redox modulatory therapy. Am J Respir Crit Care Med 2005, I 72(4):4I7-422.

9. DeForge LE, Fantone JC, Kenney JS, Remick DG: Oxygen radical scavengers selectively inhibit interleukin 8 production in human whole blood. J Clin Invest 1992, 90(5):2123-2129.

I0. Tanaka C, Kamata H, Takeshita H, Yagisawa H, Hirata H: Redox regulation of lipopolysaccharide (LPS)-induced interleukin-8 (IL-8) gene expression mediated by NF kappa B and AP-I in human astrocytoma $\mathbf{U} \mathbf{3 7 3}$ cells. Biochem Biophys Res Commun 1997, 232(2):568-573.

II. Fahy JV, Kim KW, Liu J, Boushey HA: Prominent neutrophilic inflammation in sputum from subjects with asthma exacerbation. J Allergy Clin Immunol I995, 95(4):843-852.

12. Wark PA, Johnston SL, Moric I, Simpson JL, Hensley MJ, Gibson PG: Neutrophil degranulation and cell lysis is associated with clinical severity in virus-induced asthma. Eur Respir J 2002, I9(I):68-75.

13. Drost EM, Skwarski KM, Sauleda J, Soler N, Roca J, Agusti A, MacNee $W$ : Oxidative stress and airway inflammation in severe exacerbations of COPD. Thorax 2005, 60(4):293-300.

14. Papi A, Bellettato CM, Braccioni F, Romagnoli M, Casolari P, Caramori G, Fabbri LM, Johnston SL: Infections and airway inflammation in chronic obstructive pulmonary disease severe exacerbations. Am J Respir Crit Care Med 2006, I 73( I 0): I I | 4- I I 2 I.

15. Underhill DM, Ozinsky A: Toll-like receptors: key mediators of microbe detection. Curr Opin Immunol 2002, I 4(I): I03-I I0. 
16. Hayashi F, Means TK, Luster AD: Toll-like receptors stimulate human neutrophil function. Blood 2003, 102(7):2660-2669.

17. Heil F, Hemmi H, Hochrein H, Ampenberger F, Kirschning C, Akira $\mathrm{S}$, Lipford G, Wagner H, Bauer S: Species-specific recognition of single-stranded RNA via toll-like receptor 7 and 8 . Science 2004, 303(5663): 1526-1529.

18. Diebold SS, Kaisho T, Hemmi H, Akira S, Reise Sousa C: Innate antiviral responses by means of TLR7-mediated recognition of single-stranded RNA. Science 2004, 303(5663): |529-|53|.

19. Lund JM, Alexopoulou L, Sato A, Karow M, Adams NC, Gale NW, Iwasaki A, Flavell RA: Recognition of single-stranded RNA viruses by Toll-like receptor 7. Proc Natl Acad Sci USA 2004, I0I(I5):5598-5603.

20. Takeda K, Akira S: Toll-like receptors in innate immunity. Int Immunol 2005, I 7(I):I-I4.

21. Wang JP, Bowen GN, Padden C, Cerny A, Finberg RW, Newburger $\mathrm{PE}$, Kurt-Jones EA: Toll-like receptor-mediated activation of neutrophils by influenza A virus. Blood 2008, I I 2(5):2028-2034.

22. Hattermann K, Picard S, Borgeat M, Leclerc P, Pouliot M, Borgeat P: The Toll-like receptor $7 / 8$-ligand resiquimod ( $R-848)$ primes human neutrophils for leukotriene B4, prostaglandin E2 and platelet-activating factor biosynthesis. FASEB J 2007, 2I(7): I575-I585.

23. Yamagata $T$, Sugiura $H$, Yokoyama $T$, Yanagisawa $S$, Ichikawa $T$, Ueshima K, Akamatsu K, Hirano T, Nakanishi M, Yamagata Y, Matsunaga $K$, Minakata $Y$, Ichinose M: Overexpression of CD-I Ib and CXCRI on circulating neutrophils: its possible role in COPD. Chest 2007, I32(3):890-899.

24. Ito K, Hanazawa T, Tomita K, Barnes PJ, Adcock IM: Oxidative stress reduces histone deacetylase 2 activity and enhances IL-8 gene expression: role of tyrosine nitration. Biochem Biophys Res Commun 2004, 3 I 5(1):240-245.

25. Hemmi H, Kaisho T, Takeuchi O, Sato S, Sanjo H, Hoshino K, Horiuchi T, Tomizawa H, Takeda K, Akira S: Small anti-viral compounds activate immune cells via the TLR7 MyD88dependent signaling pathway. Nat Immunol 2002, 3(2): 196-200.

26. Jurk M, Heil F, Vollmer J, Schetter C, Krieg AM, Wagner H, Lipford G, Bauer S: Human TLR7 or TLR8 independently confer responsiveness to the antiviral compound R-848. Nat Immunol 2002, 3(6):499.

27. DeForge LE, Preston AM, Takeuchi E, Kenney J, Boxer LA, Remick DG: Regulation of interleukin 8 gene expression by oxidant stress. J Biol Chem 1993, 268(34):25568-25576.

28. Schreck R, Rieber P, Baeuerle PA: Reactive oxygen intermediates as apparently widely used messengers in the activation of the NF-kappa B transcription factor and HIV-I. Embo J I99|, I 0(8):2247-2258.

29. Janssen-Heininger YM, Macara I, Mossman BT: Cooperativity between oxidants and tumor necrosis factor in the activation of nuclear factor (NF)-kappaB: requirement of Ras/ mitogen-activated protein kinases in the activation of NFkappaB by oxidants. Am J Respir Cell Mol Biol 1999, 20(5):942-952.

30. de Oliveira-Marques V, Cyrne L, Marinho HS, Antunes F: A quantitative study of NF-kappaB activation by $\mathrm{H2O}$ : relevance in inflammation and synergy with TNF-alpha. J Immunol 2007, I 78(6):3893-3902.

3I. Kamata H, Manabe T, Oka S, Kamata K, Hirata H: Hydrogen peroxide activates IkappaB kinases through phosphorylation of serine residues in the activation loops. FEBS Lett 2002, 5 I9( I3):23I-237.

32. Takada Y, Mukhopadhyay A, Kundu GC, Mahabeleshwar GH, Singh S, Aggarwal BB: Hydrogen peroxide activates NF-kappa B through tyrosine phosphorylation of I kappa $B$ alpha and serine phosphorylation of $\mathrm{p} 65$ : evidence for the involvement of I kappa B alpha kinase and Syk protein-tyrosine kinase. J Biol Chem 2003, 278(26):24233-2424I.

33. Ito K, Lim S, Caramori G, Chung KF, Barnes PJ, Adcock IM: Cigarette smoking reduces histone deacetylase 2 expression, enhances cytokine expression, and inhibits glucocorticoid actions in alveolar macrophages. FASEB J 200I, I5(6): I I 10-I I I 2.

34. Powers KA, Szaszi K, Khadaroo RG, Tawadros PS, Marshall JC, Kapus $A$, Rotstein OD: Oxidative stress generated by hemorrhagic shock recruits Toll-like receptor 4 to the plasma membrane in macrophages. J Exp Med 2006, 203(8): | 95|- | $96 \mid$.
35. Yanagisawa S, Sugiura $\mathrm{H}$, Yokoyama $\mathrm{T}$, Yamagata $\mathrm{T}$, Ichikawa $\mathrm{T}, \mathrm{Aka-}$ matsu K, Koarai A, Hirano T, Nakanishi M, Matsunaga K, Minakata $Y$, Ichinose $M$ : The possible role of hematopoietic cell kinase in the pathophysiology of COPD. Chest 2009, 135(I):94-101.
Publish with Biomed Central and every scientist can read your work free of charge

"BioMed Central will be the most significant development for disseminating the results of biomedical research in our lifetime. "

Sir Paul Nurse, Cancer Research UK

Your research papers will be:

- available free of charge to the entire biomedical community

- peer reviewed and published immediately upon acceptance

- cited in PubMed and archived on PubMed Central

- yours - you keep the copyright 